\title{
PERAN PEMERINTAH DESA DAN LEMBAGA ADAT DALAM MENERAPKAN HUKUM ADAT SOLO HULIR SE'ANG HALA DI DESA KOTING D KABUPATEN SIKKA
}

\author{
${ }^{1}$ Paulina Lawi, ${ }^{2}$ Danar Aswim, ${ }^{3}$ Rodja Abdul Natsir, \\ 1,2,3 Institut Keguruan Dan Ilmu Pendidikan Muhammadiyah Maumere \\ Jl. Jendral Sudirman, Waioti, Maumere Nusa Tenggara Timur \\ 1paulinalawi070@gmail.com \\ 22danaraswim@gmail.com \\ 3natsirodja15@gmail.com
}

\begin{abstract}
This study aims to determine the extent of the Role of the Village Government and Customary Institutions in implementing Customary Law and the Effectiveness of the Implementation of Customary Sanctions according to Village Regulation Number 07 of 2018 concerning the Implementation of Customary Sanctions solo hulir sea'ng hala. This research method is carried out with a qualitative descriptive approach. The data sources used are primary data sources and secondary data sources. The informants involved in the research were the Village Head, Customary Head and BPD. Data collection techniques used are observation, interviews and documentation studies. Data analysis techniques which include data collection, data reduction, conclusion drawing and verification. The results of the research that the role of the village government as a mediator, facilitator, motivator, judge of peace and customary institutions act as mediator, regulator, judge of peace. The effectiveness of the application of customary sanctions by the Koting D Village Government can be said to be effective, because the application of customary sanctions is actually carried out and is right on target and these rules are first socialized to the community before they are implemented so that people understand the regulations made.
\end{abstract}

Keywords: The Role of the Village Government, Traditional Institutions, Solo Customary Law se'ang hala

\begin{abstract}
Abstrak
Penelitian ini bertujuan untuk mengetahui sejauh mana Peran Pemerintah Desa dan Lembaga Adat dalam menerapkan Hukum Adat dan Efektivitas Penerapan Sanksi Adat menurut Peraturan Desa Nomor 07 Tahun 2018 Tentang Penyelenggaraan Sanksi Adat solo hulir sea'ng hala. Metode penelitian ini dilaksanakan dengan pendekatan deskriptif kualitatif. Sumber data yang digunakan yaitu sumber data primer dan sumber data sekunder. Informan yang terlibat dalam penelitian adalah Kepala Desa, Ketua Adat dan BPD. Teknik pengumpulan data yang digunakan adalah teknik observasi, wawancara dan studi dokumentasi. Teknik analisis data yang meliputi pengumpulan data, reduksi data, penarikan kesimpulan dan verifikasi. Hasil penelitian bahwa Peran Pemerintah Desa sebagai sebagai Mediator, Fasilitator, Motivator, Hakim Perdamaian Dan Lembaga Adat berperan sebagai sebagai Mediator, Regulator, Hakim Perdamaian. Efektivitas penerapan sanksi adat oleh Pemerintah Desa Koting D dapat dikatakan efektif, karena penerapan sanksi adat itu benar-benar dijalankan dan tepat sesuai sasaranya dan aturan tersebut sebelum dijalankan terlebih dahulu disosialisasikan kepada masyarakat sehingga masyarakat mengerti dengan peraturan yang dibuat.
\end{abstract}

Kata Kunci: Peran Pemerintah Desa, Lembaga Adat, Hukum Adat Solo hulir se’ang hala

\section{PENDAHULUAN}

Pemerintah Desa menjalankan perannya berdasarkan Undang-Undang Republik Indonesia Nomor 06 Tahun 2014 Tentang Desa, yakni Kepala Desa diberi tugas untuk menyelenggarakan Pemerintahan Desa, melaksanakan Pembangunan Desa, pembinaan kemasyarakatan Desa, dan pemberdayaan masyarakat Desa [1]. Pelaksanaan pembangunan atau pembinaan kemasyarakatan di Desa tidak terlepas dengan penegakan hukum adat. Hukum adat di wilayah Republik Indonesia masih diberlakukan dan dilestarikan termasuk Lembaga Adat. Menurut Undang-Undang Nomor 06 Tahun 2014 Tentang Desa Pasal 1 menyebutkan bahwa Desa adalah Desa dan Desa adat atau yang disebut dengan nama lain, selanjutnya disebut Desa, adalah kesatuan masyarakat hukum yang memiliki batas 
wilayah yang berwenang untuk mengatur dan mengurus urusan pemerintahan, kepentingan masyarakat setempat berdasarkan prakarsa masyarakat, hak asal usul, dan/atau hak tradisional yang diakui dan dihormati dalam sistem pemerintahan Negara Kesatuan Republik Indonesia. [1]. Pemerintah Desa dan Badan Permusyawaratan Desa berwenang membentuk regulasi Peraturan Desa dan Penerapan hukum untuk menjalankan pemerintahannya di Desa namun regulasi yang dibuat harus merujuk pada Undang-Undang yang berlaku dan harus ditinjau dengan kebiasaan atau adat setempat.

Desa Koting D merupakan salah satu Desa yang berada di wilayah Kabupaten Sikka, Nusa Tenggara Timur. Salah satu produk hukum yang dibuat oleh Pemerintah Desa bersama Badan Permusyawaratan Desa adalah Peraturan Desa Nomor 07 Tahun 2018 Tentang Penyelenggaraan Sanksi Adat solo hulir se'ang hala. Pemerintah Desa Koting D bersama Ketua Adat mengambil sebuah keputusan bersama untuk menerapkan Peraturan pencemaran nama baik yang di atur oleh Peraturan Desa Nomor 07 Tahun 2018 Tentang Penyelenggaraan Sanksi Adat solo hulir se'ang hala. Solo hulir se'ang hala merupakan hukum adat yang di masukan kedalam Peraturan Desa karena solo hulir se'ang hala sendiri mempunyai arti mencemarkan nama baik atau menjelekkan nama seseorang di depan umum dengan tuduhan tertentu untuk diketahui oleh semua orang atau secara umum, didalam hukum adat sendiri pencemaran nama baik merupakan suatu tindakan yang tidak baik atau jahat. Terhadap sanksi ini akan dikenakan terhadap orang pribadi yang dengan sengaja melakukan pencemaran nama baik sehingga merugikan orang lain secara psikologis [2]. Hal itu sendiri akan makin berdampak menjadi buruk dimata masyarakat umum, hukum adat ini dibentuk dengan tujuan untuk menekan atau memberikan sanksi kepada orang yang melanggar hukum adat itu.

Pembentukan Peraturan Desa dan hukum adat keduanya tidak dapat dipisahkan sehingga tidak terjadi benturan antara hukum adat dan Peraturan Desa, memahami Peraturan Desa maka tidak terlepas dari memahami hukum adat yang hidup dalam masyarakat Desa dan berkembang serta dilestarikan oleh masyarakat sebagai bagian kehidupan masyarakat Desa. Sehingga keberadaan Hukum adat menjadi bagian yang tidak terpisah dalam pelaksanaan Pemerintah Desa. Hal ini dipertegas dalam Pasal 81 Ayat (3) Undang-Undang Nomor 06 Tahun 2014 bahwa Pelaksanaan Pembangunan Desa dilakukan dengan memanfaatkan kearifan lokal dan sumber daya alam Desa [1].

Dengan demikian konsepsi dari implementasi kearifan lokal adalah memanfaatkan hukum adat sebagai pedoman dan pembangunan di Desa, Pemerintah Desa dapat menerapkan hukum adat setempat atau kearifan lokal (local wisdom) sesuai dengan harapan masyarakat setempat, serta sebagai upaya pelestarian nilai kearifan local terutama bagi generasi millennial [2,3]. Hukum adat solo hulir se'ang hala sampai saat ini masih dipertahankan oleh masyarakat Desa Koting D.

\section{KAJIAN PUSTAKA}

Peran Kepala Desa dalam menyelesaikan konflik antar warga menurut Nordohlt dengan indikator sebagai berikut:

a. Peran sebagai motivator yaitu peran Kepala Desa sebagai pendorong dan pemberi semangat kepada masyarakat setempat, agar tidak melakukan tindakan - tindakan negetif sehingga apa yang diharapkan dapat lebih berkembang dan terjaminya stabilitas keamanan dan ketartiban masyarakat, suatu saat dapat menjadi penopang perekonomian yang ada.

b. Peran sebagai fasilitator dalam hal ini Kepala Desa sebagai orang tua yang memberikan bantuan dan menjadi narasumber yang baik untuk berbagi permasalahan serta mefasilitasi kegitan - kegiatan di Desa.

c. Peran sebagai mediator Kepala Desa menjadi penengah / penetralisir antar warga yang saling berkonflik dan mempertemukan satu dengan yang lainya sehingga kata sepakat dan perdamaian dapat terjalin [4].

Menurut Undang-Undang Nomor 06 Tahun 2014 Tentang Desa, Pasal 95 disebutkan bahwa Lembaga Adat Desa merupakan lembaga yang menyelenggarakan fungsi adat istiadat dan menjadi bagian dari susunan asli Desa yang tumbuh dan berkembang atas prakarsa masyarakat Desa [1]. Kemudian lebih lanjut berdasarkan Peraturan Menteri Dalam Negeri Nomor 18 Tahun 2018 Tentang Lembaga Kemasyarakatan Desa dan Lembaga Adat Desa, pada Pasal 1 Angka 3 disebutkan bahwa Lembaga Adat Desa atau sebutan lainnya yang selanjutnya disingkat LAD adalah lembaga yang 
menyelenggarakan fungsi adat istiadat dan menjadi bagian dari susunan asli Desa yang tumbuh dan berkembang atas prakarsa masyarakat Desa [5].

Menurut Ade Saptomo Hukum adat adalah sistem aturan berlaku dalam kehidupan masyarakat Indonesia yang berasal adat kebiasaan, yang secara turun temurun dan ditaati oleh masyarakat sebagai tradisi bangsa Indonesia. Umumnya, hukum dipahami sebagai seperangkat aturan atau norma, tertulis maupun tidak tertulis yang mengkategorikan suatu perilaku benar atau salah [6].

\section{METODE PENELITIAN}

Penelitian ini menggunakan metode deskriptif kualitatif. Menurut Moleong adalah penelitian yang bermaksud untuk memahami fenomena tentang apa yang dialami oleh subjek penelitian secara holistik dan dengan cara dalam bentuk kata-kata dan bahasa, pada suatu konteks khusus yang alamiah dan dengan memanfaatkan berbagai metode alamiah [7]. Penelitian ini berlokasi di Desa Koting D Kabupaten Sikka. Sumber data yang digunakan dalam penelitian ini adalah sumber data primer dan sekunder. Sugiyono mendefinisikan sumber data primer dan data sekunder. Data primer merupakan data yang diperoleh langsung dari informan [8]. yaitu Kepala Desa, Ketua Adat dan Ketua BPD. Sedangkan sumber data sekunder yaitu data pendukung untuk melengkapi keakuratan dari penelitian ini teknik Pengumpulan data adalah melalui observasi, wawancara dan dokumentasi yang secara langsung dapat ditempat penelitian [8] dengan titik fokus Peran Pemerintah Desa Dan Lembaga Adat Dalam Menerapkan Hukum Adat Solo Hulir Se'ang Hala di Desa Koting D Kecamatan Koting Kabupaten Sikka.

\section{HASIL DAN PEMBAHASAN}

1. Peran Pemerintah Desa dan Lembaga Adat dalam menerapkan Hukum Adat menurut Peraturan Desa Nomor 07 Tahun 2018 Tentang Penyelenggaraan Sanksi Adat solo hulir sea'ng hala.

Istilah adat solo hulir se'ang hala mempunyai arti mencemarkan nama baik atau menjelekkan nama seseorang di depan umum dengan tuduhan tertentu untuk diketahui oleh semua orang atau secara umum. Untuk menyelesaikan masalah ini Pemerintah Desa melakukan beberapa peran diantaranya sebagai berikut :

\section{a. Sebagai Motivator}

Rini Ulfatul Hasanah dalam penelitiannya menguraikan peran Kepala Desa sebagai motivator lebih mengarah kepada penggerak swadaya masyarakat. Dalam pengertian, pembangunan sebuah Desa bergantung pada kolaborasi antara pemimpin yang baik dan masyarakatnya [9]. Sedangkan peran Kepala Desa di Desa Koting D memberikan motivasi dan dorongan kepada masyarakatnya untuk melakukan tindakan-tindakan positif. Tindakan positif ini diharaapkan dapat tercapainya kebaikan bersama (conum communion) bagi masyarakat itu sendiri (dibidang perekonomian, bidang keamanan dan sebagainya). Jadi peran Kepala Desa bukan hanya menyelenggarakan pemerintahan saja atau atau dibidang pemerintahan, akan tetapi Kepala Desa juga mempunyai tugas untuk mendorong dan memberikan dukungan kepada masyarakatnya.

b. Sebagai Fasilitator

Aksan dkk, dalam penelitianya mengungkapkan bahwa peran Kepala Desa sebagai fasilitator menjalankan perannya dalam hal memfasilitasi atau melengakapi kebutuhan yang diperlukan oleh masyarakat setempat [10]. Peran yang sama juga di dijalankan oleh Pemerintah Desa Koting D bahwa Peran Kepala Desa dalam hal ini sebagai orang yang memfasiliatasi kegiatan-kegiatan yang berada di Desa, Kepala Desa berperan sebagai penengah yang baik dalam menyelesaikan permasalahan yang terjadi di Desa, Kepala Desa juga menjadi narasumber yang baik untuk berbagai permasalahan kegiatan-kegiatan di Desa.

c. Sebagai Mediator

Sri lestari Rahayu dkk, menjelaskan bahwa peran pemerintah Desa sebagai mediator membantu pihak-pihak yang bermasalah atau bersengketa untuk memperoleh kesepakatan atau perjanjian yang memuaskan masing-masing pihak dengan kata lain mediator sebagai 
pihak penengah yang harus memiliki sifat netral dan tidak membuat keputusan atau kesimpulan bagi para pihak tetapi menunjang fasilitator untuk terlaksananya dialog antara pihak dengan suasana keterbukaan, kejujuran, dan tukar pendapat untuk tercapainya mufakat [11]. Kepala Desa berperan sebagai penengah antara warga yang saling berkonflik dan berusaha untuk mencapai atau sepakat antara kedua belah pihak sehingga memperoleh perdamaian.

\section{d. Sebagai Hakim Perdamaian}

Samuel Dharman Putra Naainggolan, mengemukakan sebagai hakim perdamaian bagi masyarakatnya merupakan suatu sarana untuk membuat suatu hukum yang mengatur hak dan kewajiban subjek hukum agar masing-masing menjalankan kewajibanya dengan baik dan mendapatkan haknya secara wajar [12]. Disamping itu kedudukan Kepala Desa bukan hanya menyelenggarakan pemerintahan saja akan tetapi Kepala Desa juga mempunyai wewenang sebagai hakim perdamaian dimana tugas seorang Kepala Desa, harus mampu menyelesaikan perkara atau konflik yang ada dan terjadi dalam kehidupan masyarakat.

Pemerintah Desa dalam melaksanakan tugasnya terlebih dahulu melakukan sosialisasi tentang Peraturan Desa yang mengatur tentang Solo hulir se'ang hala. Kemudian dalam proses penyelesaian masalah Pemerintah Desa bertindak sebagai fasilitator, mediator dan hakim perdamaian yang akan menindak lanjuti pelangaran yang dilakukan sesuai dengan ketentuan sanksi dalam Peraturan Desa Nomor 07 Tahun 2018 Tentang Penyelenggaraan Sanksi Adat solo hulir se'ang hala, serta akan dilanjutkan ke tingkat Desa untuk menyelesaikan masalah tersebut dengan membayar denda jika terbukti dan dinyatakan bersalah. Pemerintah Desa menyediakan sarana dan prasarana untuk menyelesaikan permasalahan yang terjadi sesuai dengan keputusan dan aturan yang berlaku di tingkat Desa itu sendiri. Mediasi merupakan salah satu cara yang dilakukan oleh Pemerintah Desa dalam mencapai kata damai antar masyarakat, hal ini juga bisa dilihat dan dirasakan oleh masyarakat. Selama menjalankan tugasnya Pemerintah Desa berpedoman pada ketentuan Peraturan Perundang-undangan yang berlaku khususnya Pasal 26 Ayat (4) huruf "k" Undang-Undang No. 06 Tahun 2014 Tentang Desa disebutkan bahwa salah satu kewajiban Kepala Desa adalah menyelesaikan perselisihan masyarakat di Desa.

Lembaga Adat di Desa Koting D ikut berperan dalam menyelesaikan konflik akibat solo hulir se'ang hala (pencemaran nama baik) sekaligus mengawasi jalannya pelaksanaan sanksi adat sesuai dengan nilai-nilai dan norma-norma adat yang hidup di dalam masyarakat setempat dengan merujuk pada Peraturan Desa solo hulir sea'ng hala. Ayi Haryani, mengemukakan bahwa Lembaga Adat harus mampu mengendalikan komunitas adat untuk bersikap dan berperilaku sesuai dengan norma yang berlaku dalam kelompok masyarakat tersebut serta dapat memfungsikan Lembaga Adat sebagai wadah dimana dapat menyelesaikan perselisihan yang terjadi dimasyarakat sesuai dengan kebiasaan kelompok masyarakat itu sendiri [13]. Lebih lanjut menurut Samsuddin, Lembaga Adat ikut ambil bagian dalam menyelesaikan permasalahan yang ada, dengan melakukan musyawarah bersama dengan Kepala Desa, dan aparatur Desa yang bersangkutan, sehingga terjadi perdamaian antara kedua belah pihak dan kedudukan Lembaga Adat ini sudah diakui oleh Peraturan Desa dan memilki kerja sama dengan Pemerintah Desa untuk menyelesaikan perselisihan yang terjadi dimasyarakat dengan tujuan mendamaikan [14]. Hal ini menunjukan bahwa kedudukan Lembaga Adat sama pentingnya dengan Pemerintah Desa dalam menyelesaikan setiap permasalahan yang terjadi di Desa khususnya yang berkaitan dengan solo hulir sea'ng hala sehingga tercapainya perdamaian.

Peran Lembaga Adat ketika terjadi konflik solo hulir se'ang hala bersama-sama dengan Kepala Desa sebagai mediator, hakim perdamaian dan regulator, yang membantu dalam proses mediasi setiap masalah khususnya dengan solo hulir se'ang hala serta menentukan sanksi adat berupa denda yang harus dibayar oleh pelaku yang melanggar Peraturan Desa tersebut. Dalam penerapan sanksi adat solo hulir se'ang hala kepada para pelaku pelanggaran solo hulir se'ang hala (pencemaran nama baik) secara adat telah ditetapkan sesuai Peraturan Desa Nomor 07 Tahun 2018. Peran Pemerintah Desa dan Badan Permusyawaratan Desa di dalam lingkungan hukum adat sebagai pimpinan wilayah Desa, Kepala Desa ikut serta dalam setiap proses keberlangsungan proses penyelesaian suatu masalah serta bertindak sebagai penasihat disetiap permasalahan yang 
dilakukan masyarakat dan untuk BPD, selain sebagai penyambung komunikasi antara masyarakat dengan Pemerintah Desa, BPD juga berperan penting demi terjaganya hubungan baik antara masyarakat.

Pemerintah Desa dan Lembaga Adat di Desa Koting D dalam menyelesaikan masalah samasama memliki peran yaitu sebagai mediator dan hakim perdamaian. Hal ini dapat dirasakan dan dilihat bagaimana Kepala Desa dan Ketua Adat yang saling menjalin kerja sama yang harmonis dan berkoordinasi membantu menyelesaikan konflik antara warga masyarakat. Kepala Desa memfasilitasi jalannya proses penyelesaian masalah yang terjadi antar warga. Sedangkan untuk menyelesaikan perkara itu berdasarkan keputusan Ketua Lembaga Adat beserta anggotanya, sehingga tidak terlepas dari jalinan kerja sama antar mereka, seperti yang sudah pernah terjadi konflik antara warga mengenai pencemaran nama baik, Pemerintah Desa dan Lembaga Adat harus mencari tahu pokok permasalahan yang ada dengan terlebih dahulu melakukan mediasi antara pihak pelaku dan pihak korban yang bersangkutan, sehingga terjadi perdamaian antara kedua belah pihak.

\section{Efektivitas Penerapan Sanksi Adat menurut Peraturan Desa Nomor 07 Tahun 2018 Tentang Penyelenggaraan Sanksi Adat solo hulir sea'ng hala}

Menurut Barda Narwawi Arief efektivitas mengandung arti keefektifan pengaruh efek keberhasilan atau kemanjuran atau kemujaraban. Membicarakan keefektifan hukum tentu tidak terlepas dari penganalisisan terhadap karakteristik dua variabel terkait yaitu karakteristik atau dimensi dari objek sasaran yang dipergunakan [15]. Menurut Permata Wesha efektivitas adalah keadaan atau kemampuan berhasilnya suatu kerja yang dilakukan oleh manusia untuk memberi guna yang diharapkan [16]. Menurut Cambel J.P pengukuran efektivitas secara umum dan yang paling menonjol salah satunya adalah keberhasilan program [17]. Pemerintah Desa dan Lembaga Adat di Desa Koting D melihat tentang efektivitas dalam penerapan sanksi adat menurut mereka efektif, karena masyarakat mengikuti aturan yang dibuat oleh Pemerintah Desa, dalam arti mempunyai kesadaran akan hal tersebut. Selama proses penyelesaian masalah Pemerintah Desa mempunyai cara tersendiri untuk menyelesaikan masalah sehingga masalah tersebut dapat diselesaiakan sampai di tinggat Desa saja tanpa dibawa ke ranah peradilan, hal ini terbukti dengan adanya berita acara penyelesaian masalah pencemaran nama baik atau istilah adatnya Hera Tada yang artinya setelah dilakukan musyawarah maka kedua belah pihak menyetujui semua kesepakatan-kesepakatan yang telah di tentukan. Segala bentuk pelanggaran terhadap adat istiadat Desa Koting D, dikenakan sanksi adat sesuai keputusan Lembaga Adat dari sanksi adat terhadap pencemaran nama baik atau solo hulir se'ang hala telah ditetapakan sesuai Peraturan Desa Nomor 07 Tahun 2018 Tentang Penyelenggaraan Sanksi Adat solo hulir se'ang hala yaitu dikenakan terhadap orang pribadi yang dengan sengaja melakukan pencemaran nama baik sehingga merugikan orang lain secara psikologis.

Penerapan sanksi adat solo hulir se'ang hala (pencemaran nama baik)yang telah ditetapkan oleh Lembaga Adat di Desa Koting D, sejauh ini selalu dipatuhi oleh masyarakat. Penerapan sanksi adat terhadap pelanggaran-pelanggaran hukum adat sangat berlaku efektif dalam masyarakat sendiri, karena membuat para pelaku tidak lagi melakukan kesalahan yang sama, penerapan sanksi adat sangat efektif dalam mencegah permasalahan yang muncul dikalangan masyarakat, karena hukum adat bertujuan untuk memberikan penyelesaian secara damai walaupun diiringi dengan sanksi, sanksi yang di berikan kepada pelaku berupa denda dan lain sebagainya. Namun denda ini bukan berarti ingin memberatkan para pihak yang bermasalah, melainkan hanya sebagai bentuk pembelajaran, agar tidak mengulanginya lagi.

Solo Hulir Se'ang Hala sendiri artinya pencemaran nama baik, ketika penyelesaian masalah itu dilakukan atas tuntutan si korban, maka si pelaku wajib dikenakan sanksi adat berupa beras $25 \mathrm{~kg}$, satu ekor babi seberat $25 \mathrm{~kg}$ dan moke (minuman keras tradisional) 10 liter. Pembayaran sanksi tersebut dalam adat setempat disebut Hera Tada Atas Denda tersebut wajib dipatuhi oleh masyarakat, khusunya di Desa Koting D sebagai pengayom hidup dalam bermasyarakat. 
p-ISSN : 2655-7304

e-ISSN : 6655-8953

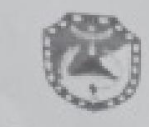

\section{PEMERINTAH KABUPATEN SIKKA}

KECAMATAN KOTING

DESA KOTING D

BERITA ACARA PENYELESAIAN MASAIAH PENCEMARAN NAMA BAIK

( HERA TADA )

Berkaitan dengan Penyelesainan Masalah Pencemaran Nama Baiki Hera Tade ) maka pada Hari ini :

$\begin{array}{ll}\text { Han / Tanggal } & \text { : Senin, 03 Juni } 2019 \\ \text { Jam. } & : 11.00 \text { sampai selesai } \\ \text { Tempat } & \text {; Kantor Desa Koting D }\end{array}$

Telah dilakukan Froses Penyelesaian masalah Adat yang dihadiri oleh = Kepala Desa, Skekretaris Desa, Unsur Perangloat Desa,BPD,PJ Desa Persiapan Watu Repa, Kapolsck

"Nele, Kapospol Koting, Babinsa Kecamatan Koting, RT/RW, Kepala Dusun, Lembaga Adat serta wakil-wakil Kelompok Masyarakat ( Daftar Hadir terlampir ).

Setelah dilakukan Musyawarah maka Kedua Bclah Pihak menyetujui semua kesepakatanlcesepakatan yang telah ditentukan

Demikian Berita Acara ini di buat untuk dipergunakan sebagaimana mestanya

Mengetahui.

Ketua BPD

Blasius Aprinus
Gchak, 03 Juni 2019

Kepala Desa Koting D

Gregorius Nong

Wakil Masyarakat yang hadir

\begin{tabular}{|c|c|c|c|}
\hline No & Nama Wakil Masyarakat & Jabatan & Tanda Tangan \\
\hline 1 & Ajutor Botu & Anggotn Lenhaga Mdat & Alus \\
\hline 2 & Henderika Dua Heret. & Ketua Rw 05 & \\
\hline 3 & Launensia Yudit & Repala Dusun Gehak Lau & \\
\hline 4 & Geradus Nong Goan & Ketua RT 11 & \\
\hline
\end{tabular}

Catatan:
1. Beras $25 \mathrm{~kg}$
2. Babi 1 ekor berat $25 \mathrm{Kg}$
3. Moke 10 Liter

Sumber : Kamera pengambilan data 2021 (Berita Acara penyelesaian masalah pencemaran nama baik) 
Table 1.1 Wawancara

\begin{tabular}{|c|c|c|}
\hline Aspek yang diwawancara & Subyek 1 & Subyek 2 \\
\hline $\begin{array}{l}\text { Bagaimana Peran Pemerintah Desa } \\
\text { dan Lembaga Adat Dalam Penerapan } \\
\text { Sanksi Adat Menurut Peraturan Desa } \\
\text { Nomor 07 Tahun 2018 Tentang } \\
\text { Penyelenggaraan Sanksi Adat Solo } \\
\text { Hulir Sea'ng Hala di Desa Koting D } \\
\text { Kecamatan Koting Kabupaten Sikka? }\end{array}$ & $\begin{array}{l}\text { Peran Pemerintah Desa sebelum } \\
\text { terjadi masalah yaitu melakukan } \\
\text { sosialisasi kepada masyarakat } \\
\text { tentang Peraturan Desa yang } \\
\text { mengatur tentang Solo Hulir } \\
\text { Se'ang Hala. Dalam proses } \\
\text { penyelesaian pemerintah Desa } \\
\text { sebagai mediator, hakim } \\
\text { perdamaian dan regulator. Pihak } \\
\text { Pemerintah Desa akan menindak } \\
\text { lanjuti pelangaran yang dilakukan } \\
\text { sesuai dengan PERDES dan akan } \\
\text { dilanjutkan ke tingkat Desa untuk } \\
\text { menyesaikan masalah. Pihak Desa } \\
\text { tentu menyediakan sarana dan } \\
\text { prasarana untuk menyelesaikan } \\
\text { permasalahan yang terjadi sesuai } \\
\text { dengan keputusan dan aturan yang } \\
\text { berlaku di tingkat Desa itu sendiri, } \\
\text { mediasi merupakan salah satu cara } \\
\text { yang dilakukan oleh Pemerintah } \\
\text { Desa dalam mencapai kata damai } \\
\text { antar masyarakat. }\end{array}$ & $\begin{array}{l}\text { Peran Lembaga Adat ketika terjadi } \\
\text { konflik solo hulir se'ang hala } \\
\text { mereka berperan sama-sama } \\
\text { dengan Kepala Desa sebagai } \\
\text { mediator, hakim perdamaian dan } \\
\text { regulator, yang membantu dalam } \\
\text { proses mediasi setiap masalah } \\
\text { khususnya terkait solo hulir se'ang } \\
\text { hala serta menentukan sanksi adat } \\
\text { berupa bayar denda adat kepada } \\
\text { korban. Namun disini keputusan } \\
\text { akan suatu pelanggaran itu } \\
\text { diputuskan oleh Lembaga Adat. }\end{array}$ \\
\hline $\begin{array}{l}\text { Bagaimana Efektifitas Penerapan } \\
\text { Sanksi Adat Menurut Peraturan Desa } \\
\text { Nomor 07 Tahun 2018 Tentang } \\
\text { Penyelenggaraan Sanksi Adat Solo } \\
\text { Hulir Sea'ng Hala di Desa Koting D } \\
\text { Kecamatan Koting Kabupaten Sikka? }\end{array}$ & $\begin{array}{l}\text { Pemerintah Desa Koting D menilai } \\
\text { bahwa dalam proses penyelesaian } \\
\text { masalah di Desa Koting D itu } \\
\text { efektif, karena masyarakat } \\
\text { mengikuti aturan yang dibuat oleh } \\
\text { Pemerintah Desa, dalam arti } \\
\text { mempunyai kesadaran akan hal } \\
\text { tersebut. Dalam proses } \\
\text { penyelesaian juga pemerintah Desa } \\
\text { mempunyai cara tersendiri untuk } \\
\text { menyelesaikan masalah sehingga } \\
\text { masalah tersebut diselesaiakan } \\
\text { sampai di Desa saja hal ini terbukti } \\
\text { dengan adanya berita acara } \\
\text { penyelesaian masalah pencemaran } \\
\text { nama baik. }\end{array}$ & $\begin{array}{l}\text { Efektif karena sudah ada aturan } \\
\text { yang mengatur, sehingga } \\
\text { masyarakat juga akan pikir-pikir } \\
\text { melakukan hal-hal yang dilarang } \\
\text { dalam PERDES tersebut. Serta } \\
\text { keputusan dari Lembaga Adat } \\
\text { wajib untuk dipatuhi. }\end{array}$ \\
\hline
\end{tabular}

Keterangan : Tabel diatas merupakan pedoman wawancara dengan informan ditempat penelitian 
p-ISSN : 2655-7304

e-ISSN : 6655-8953

\section{KESIMPULAN DAN SARAN}

Berdasarkan hasil penelitian Peran Pemerintah Desa dan Lembaga Adat dalam menerapkan hukum adat Solo Hulir Se'ang Hala di Desa Koting D Kabupaten Sikka, dapat dikatakan berjalan efektif karena merujuk pada Peraturan Perundang-Undangan khususnya Undang-Undang Nomor 06 Tahun 2014 Tentang Desa, serta Pemerintah Desa mempunyai produk hukum desanya sendiri yaitu Peraturan Desa Nomor 07 Tahun 2018 Tentang Penyelenggaraan Sanksi Adat, produk hukum tersebut lahir dengan melihat hukum adat sebagai bentuk dari kearian lokal. Penerapan pemberian sanksi adat solo hulir se'ang hala yang telah ditetapkan oleh Lembaga Adat dipatuhi oleh masyarakat Desa Koting D. Penerapan sanksi adat terhadap pelanggaran-pelanggaran hukum adat tersebut berlaku efektif karena membuat para pelaku tidak mengulangi kesalahan yang sama, penerapan sanksi ini merupakan upaca preventif mencegah permasalahan yang muncul dikalangan masyarakat, karena hukum adat bertujuan untuk memberikan penyelesaian secara damai walaupun diiringi dengan sanksi yang di berikan kepada pelaku berupa denda dan lain sebagainya.

\section{DAFTAR PUSTAKA}

[1] Undang - Undang Nomor 06 Tahun 2014 Tentang Desa.

[2] Peraturan Desa Nomor 07 Tahun 2018 Tentang Penyelenggaraan Sanksi Adat

[3] Nordholt, H.S. (2007). Politik Lokal Di Indonesia. Leiden: Kera Sama KITLV dan Yayasan Pustaka Obor Indonesia.

[4] Peraturan Menteri Dalam Negeri Nomor 18 Tahun 2018 Tentang Lembaga Kemasyarakatan Desa dan Lembaga Adat Desa.

[5] Ade Saptomo. (2010). Hukum dan Kearifan Lokal Revitalisasi Hukum Adat Nusantara. Jakarta: PT. Grasindo

[6] Moleong, L.J. (2011). Metodologi Penelitian Kualitatif Edisi Revisi. Bandung: PT. Remaja Rosdakarya.

[7] Sugiyono. (2015). Metode Penelitian Kombinasi ( mix methods). Bandung: Alfabeta.

[8] Rini Ulfatul Hasanah.(2020). Peran Kepala Desa sebagai Motivator Pembangunan di Desa, Jurnal Paradigma Madani, Vol 7, No. 2, Hal. 1-10.

[9] Aksan dkk.(2018). Peran Kepala Desa Dalam Meningkatkan Pembangunan Desa. Jurnal Neososietal, Vol 3.3, No.1.

[10] Sri lestari Rahayu dkk. (2016). Penguatan Fungsi Kepala Desa Sebagai Mediator Perselisihan Masyarakat Di Desa. Yustisia. Vol 5. No.2.

[11] Samuel Dharman Putra Naainggolan. (2005). Kedudukan Kepala Desa Sebagai Hakim Perdamaian.UBELAJ, Vol 3 No 1.

[12] Sri lestari Rahayu dkk. (2016). Penguatan Fungsi Kepala Desa Sebagai Mediator Perselisihan Masyarakat Di Desa. Yustisia. Vol 5. No.2.

[13] Samsuddin. (2021). Peran Lembaga Adat Dalam Perancanaan Pembangunan Desa Pudak, Jurnal Tanah Pilih. Vol.1 No.1.

[14] Arief Nawawi Barda. (2013). Kapita Selekta Hukum Pidana. Bandung: Citra Aditya.

[15] Wesha, Permata. ( 2007). Kinerja Organisasi. Jakarta Rineka Cipta Jaya.

[16] Campbell, J.P. (2005). Teori Efektivitas, Bandung: Erlangga. 